\title{
Wykładnia translacyjna tekstów z zakresu prawa
}

\author{
Translational interpretation of legal texts
}

\author{
Anna BONEK \\ Uniwersytet Warszawski/ University of Warsaw \\ E-mail: anna.bonek@uw.edu.pl
}

\begin{abstract}
According to the anthropocentric theory of human languages by F. Grucza and the human language linguistics by S. Grucza every understanding is the understanding of a particular person. Therefore while interpreting a legal text, translator should apprehend original text's interpretation as the lawyer would. It means that in recreating the law texts, the translator should base his understanding on rules used by lawyers. Translational interpretation, in my understanding, includes as follows: rules of law interpretation (tailored especially for translators), text receiver and author of source and target texts, as well as the type of text and translational goal.
\end{abstract}

Keywords: understanding, translation, legal texts, anthropocentric theory of human Language, interpretation of legal texts

\section{Wstęp ${ }^{1}$}

Rozważania zarysowane w niniejszym artykule są wynikiem moich obserwacji dokonanych zarówno podczas badań naukowych oraz mojej działalności prawniczej i translacyjnej. Rozważania te wywodzą się zarówno z założeń antropocentrycznej teorii języków ludzkich prof. Franciszka Gruczy, jak i założeń lingwistyki języków specjalistycznych prof. Sambora Gruczy. Natomiast moje podejście do przepisów prawnych opiera się na metodzie dogmatycznej, dzięki której system prawa rozumiany jest jako uporządkowany, spójny i zupełny zbiór norm obowiązujących, prawo zaś jest obiektem danym przez prawodawcę (szerzej M. Błachut et al. 2008).

\section{Zarys problemu}

Zgodnie z założeniami antropocentrycznej teorii języków ludzkich każdy konkretny tekst jest tworem konkretnej osoby, wytworzonym przez nią na podstawie jej konkretnego języka. Natomiast za S. Gruczą przyjmuję, że każde konkretne rozumienie jest rozumieniem konkretnej osoby (por. S. Grucza 2013: 67).

Dlatego w celu odnalezienia optymalnego odpowiednika w języku docelowym nie wystarczy określić nadawcę, odbiorcę zarówno tekstu wyjściowego, jak i docelowego, cel tłumaczenia, rodzaj tekstu, lecz tłumacz powinien dążyć do zrozumienia

\footnotetext{
${ }^{1} \mathrm{~W}$ tym miejscu pragnę podziękować Panu Profesorowi Samborowi Gruczy za cenną dyskusję, która pomogła mi w sporządzaniu ostatecznej wersji niniejszego tekstu.
} 
tekstu wyjściowego w sposób możliwie zbliżony do nadawcy tekstu. Oznacza to, że tłumacz przystępujący do tłumaczenia tekstu prawnego powinien zapoznać się z innymi tekstami, które umożliwią mu poznanie zasad i reguł tworzenia, interpretowania i rozumienia tekstów prawnych i prawniczych, którymi posługują się prawnicy tworząc swoje teksty. Są to np. zasady techniki legislacyjnej, techniki wykładni prawa, komentarze do ustaw oraz podręczniki do nauki danej gałęzi prawa (M. Zieliński 2012). Jest to konieczne, ponieważ - jak słusznie twierdzi S. Grucza - teksty stworzone przez prawników są eksponentami (zastępnikami) ich wiedzy, zaś teksty przez nich stworzone mają się do ich języków w taki sposób, jak produkty do programów, na podstawie których zostały one wytworzone (por. S. Grucza 1993: 133). Dlatego dla głębszego zrozumienia tekstu wyjściowego konieczne jest rozbudowanie indywidualnej wiedzy tłumacza co najmniej o zasady, którymi kierują się prawnicy tworząc $\mathrm{i}$ interpretując teksty prawne w danym porządku prawnym.

Oznacza to, że tłumacz dokonując przekładu wyrażeń specjalistycznych nie będących tworem tak zwanego ustawodawcy, lecz doktryny, zmuszony jest rekonstruować znaczenie danej instytucji prawnej nie tylko na podstawie obowiązujących tekstów prawnych, lecz także podręczników z zakresu prawa, których adresatem są co do zasady prawnicy. Rekonstrukcja przez tłumacza znaczenia specjalistycznego wyrażenia, instytucji prawnej, czy też tekstu prawnego, dokonana zgodnie z zasadami wykładni prawnej oraz teorii translacyjnych, nazywam wykładnią translacyjną.

W dalszej części artykułu zarysuję założenia wykładni prawa wypracowane przez prawników dla celów usystematyzowania procesu rozumienia tekstów prawnych oraz przedstawię argumenty przemawiające za wykorzystaniem tych założeń na gruncie translatoryki i w pracy thumacza.

\section{Wykładnia tekstów prawnych}

W doktrynie prawnej wyróżnia się wykładnię tekstów prawnych sensu stricto i sensu largo. Mówiąc o wykładni tekstów prawnych sensu stricto prawnicy mają na myśli problemy dotyczące rozumienia przepisów prawnych, natomiast mówiąc o wykładni sensu largo prawnicy mają na myśli nie tylko czynności związane z rozumieniem tekstów prawnych, lecz również wnioskowanie $\mathrm{z}$ norm odtworzonych na podstawie tekstu prawnego o innych normach (normy wyinferowane) (M. Zieliński 2012: 44). Jednakże Autor zaznacza, że wykładnia sensu largo dotyczy nie interpretacji norm, lecz ich walidacji (obowiązywania norm), stąd swoje rozważania dotyczące wykładni prawnej skupia na jej ujęciu sensu stricto (M. Zieliński 2012: 47). Podążając za argumentacją M. Zielińskiego mówiąc o wykładni tekstów prawnych czy tez przepisów prawnych będę mieć na myśli wykładnię w jej węższym znaczeniu $^{2}$.

M. Zieliński, Autor wiodącego podręcznika dotyczącego wykładni prawa, poprzez wykładnię prawa rozumie czynności związane $\mathrm{z}$ rozumieniem tekstów praw-

${ }^{2} \mathrm{~W}$ praktyce prawniczej termin ,wykładnia prawa” rozumiany jest zarówno jako zespół czynności odnoszących się do wyrażeń, jak i rezultat tych czynności dokowanych w stosunku do owych wyrażeń (M. Zieliński 2012: 43). 
nych, a dokładniej wykładnia w jego rozumieniu, polega na odczytaniu treści wyrażonej w przepisie (M. Zieliński 2012: 44 i nast.). Zaznacza on, że prawnicy posługują się częściej terminem ,wykładnia”, podczas gdy językoznawcy i literaturoznawcy terminem ,interpretacja”, a ponadto prawnicy zasadniczo posługują się terminami „wykładnia” i ,interpretacja” zamiennie (M. Zieliński 2012: 48). Jako prawnik i lingwista, pozwolę sobie używać terminu ,wykładnia” do określania takiego procesu rozumienia tekstu, który opiera się na zasadach wykładni prawnej.

W literaturze prawniczej szeroką akceptację znalazł pogląd (M. Zieliński 2012: 53) uznanego prawnika i zarazem naukowca Jerzego Wróblewskiego, który postrzega rozumienie, jako odebranie równokształtnej informacji z informacją przekazaną (J. Wróblewski 1990: 52). Niestety trudno zgodzić się z takim poglądem bowiem jak pisze S. Grucza, każde konkretne rozumienie jest rozumieniem konkretnej osoby (S. Grucza 2013: 67), które w większym lub mniejszym stopniu będzie jedynie zbliżone do intencji nadawcy w chwili formułowania tekstu. Pomijając ten istotny fakt, stwierdzić trzeba zarazem, że dorobek doktryny wskazuje na znaczne zainteresowanie procesami rozumienia tekstu, choć zawęża go do tzw. wykładni tekstów prawnych, którą powinien kierować się prawnik w celu rekonstrukcji znaczenia tekstów i przepisów prawnych.

Ponadto J. Wróblewski dokonuje rozróżnienia pomiędzy rozumieniem a wykładnią, przy czym rozumienie pojmuje jako „rozumienie bezpośrednie” natomiast wykładnię nazywa „rozumieniem w drodze wykładni” (J. Wróblewski 1990: 58 i nast.). Z rozumieniem bezpośrednim mamy, jego zdaniem, do czynienia wtedy, gdy nie ma wątpliwości, że rozpatrywany stan faktyczny (warunki, osoby, zachowanie) mieści się w zakresie wyznaczonym przez przepis. Zatem brak jest wątpliwości odnośnie rozumienia i stosowania danego przepisu prawnego. Natomiast w razie zaistnienia takich wątpliwości znaczenie przepisu rekonstruowane jest „w drodze wykładni" (tamże).

M. Zieliński neguje, jakoby rozumienie a wykładnia były czymś zgoła odmiennym. A wręcz oddzielenie rozumienia od wykładni, doprowadziło, jego zdaniem, do stworzenia pozoru pewności prawnej dla obywatela, który w przypadku braku wątpliwości stwierdza, że do innego rozumienia niż to, które jest jego udziałem, dojść nie można (M. Zieliński 2012: 54). Ponadto upewnia to organy państwowe w przekonaniu, że ich bezpośrednie rozumienie przepisu jest decydujące, gdyż eliminuje sytuację wykładni (tamże).

M. Zieliński słusznie ukazuje, że nawet od wybranego sposobu rozumienia jednego przyimka w przepisie prawnym zależą konsekwencje prawne wynikające $\mathrm{z}$ danego przepisu (M. Zieliński 2012: 55 i nast.). Ponadto podkreśla on, że nie chodzi oto, aby po prostu rozumieć tekst, czy jakiś jego przepis, ale o to, by zrozumieć ten tekst, czy przepis zgodnie z treścią nadaną mu przez prawodawcę (M. Zieliński 2012: 58). „Rozumienie tekstu prawnego niejako z natury rzeczy wymaga więc refleksyjności (...), gdyż zrozumienie tekstu prawnego wymaga przejawienia pewnej wiedzy o twórcy tekstu" (T. Gizbert-Studnicki 1986: 52 cyt. za M. Zielińskim 2012: 58). Oznacza to, że także na tłumacza tekstów prawnych musi być nałożony obowiązek ukierunkowania swojego sposobu rozumienia tekstu w stronę sposobu rozu- 
mienia autora tekstu.

Jak pisze M. Zieliński, wykładnia przepisu prawnego, czy też tekstu prawnego, ze względu na ogromną różnorodność redakcyjną oraz wieloznaczność przepisów prawnych obejmuje bardzo szeroki krąg zachowań w celu wyinterpretowania jednoznacznych norm postępowania (M. Zieliński 2012: 58 i nast.). Normy te są niejako wyinterpretowywane przez prawników z przepisów prawnych znajdujących się $\mathrm{w}$ różnych częściach aktów prawnych. Chodzi tu o tak zwane rozczłonkowanie norm $\mathrm{w}$ przepisach prawnych. Ponadto teksty prawne formułowane są często w sposób opisowy, które mimo to powinny być odczytywane jako normy postępowania (M. Zieliński 2012: 105). Ponadto M. Zieliński twierdzi, że wszystkie elementy tekstu (nie tylko przepisy prawne) współuczestniczą w wyznaczaniu treści norm postępowania (M. Zieliński 2012: 105). Również tytuły ustawy, tytuły wewnętrzne tekstu oraz preambuła stanowią materiał interpretacyjny, umożliwiający normatywną wykładnię tekstu (tamże).

I tak np. przepis typu „Minister wyda rozporządzenie (...)” thumacz tekstu prawnego powinien rozumieć, nie jako opis bliżej nieokreślonej przyszłości, lecz jako normę kompetencyjną do wydania rozporządzenia oraz normę nakazującą określone zachowanie się w postaci wydania rozporządzenia (M. Zieliński 2012: 103).

W podręcznikach do nauki prawa oraz artykułach naukowych wymieniane są różne rodzaje wykładni prawnej. W tym miejscu skupię się w pierwszej kolejności na wykładni autentycznej, operatywnej oraz doktrynalnej, które rozróżniane są ze względu na podmiot ich dokonujący, przy tym opierać się będę na definicjach sformułowanych przez T. Staweckiego i P. Winczorka (2003). Zgodnie z nimi:

(i) wykładnia autentyczna dokonywana jest przez organ władzy publicznej, który dany przepis ustanowił. Moc wiążąca tej wykładni jest równa mocy wiążącej aktu normatywnego, w którym dana wykładnia została sformułowana (T. Stawecki/ P. Winczorek 2003: 165). Definicje legalne wyrażone w danym akcie normatywnym, nakazujące używania określonego zwrotu w konkretnym znaczeniu, ułatwiają przeprowadzenie wykładni przepisu prawnego (M. Zieliński 2012: 65);

(ii) wykładnia operatywna, zwana też wykładnią organów stosujących prawo, dokonywana jest przez te organy władzy publicznej (państwowej, samorządowej, ustawodawczej, wykonawczej i sądowniczej), które stosują prawo. Wykładnia ta wiąże organ jej dokonujący i podmioty, wobec których prawo jest stosowane. Sąd Najwyższy w drodze uchwały wyjaśnia znaczenie przepisów prawnych budzących wątpliwości w praktyce lub których stosowanie wywołało rozbieżności w orzecznictwie. Do ich podjęcia dochodzi na wniosek uprawnionego organu. Uchwały składów siedmioosobowych nie wiążą bezpośrednio nikogo, choć zachowanie niezgodne z tak zinterpretowaną normą uznane byłoby za naruszenie prawa (tamże);

(iii) wykładnia doktrynalna (naukowa) nie ma dla nikogo mocy wiążącej. Wykładnia ta dokonywana jest przez prawników (naukowców, wybitnych praktyków). Siłą autorytetu intelektualnego może oddziaływać ona na decyzje organów stosujących prawo. W komentarzach do aktów normatywnych oraz glosach do orzeczeń sformułowane są tego rodzaju wykładnie.

Wykładnia tekstu prawnego może być również zróżnicowana ze względu na sposób jej dokonywania: 
(iv) wykładnia językowa polega na dokonywaniu interpretacji prawnych przy wykorzystaniu reguł znaczeniowych (semantycznych) i konstrukcyjnych (syntaktycznych i stylistycznych) języka prawnego, a także na zastosowaniu reguł poprawnego myślenia i specyficznych reguł logiki prawniczej (T. Stawecki/ P. Winczorek 2003: 171). Przy czym odwołując się do wykładni językowej sędziowie często przytaczają definicje słownikowe danego wyrażenia (patrz np. Uchwała Sądu Najwyższego z 18.9.1989 r., VI KZP 10/82). A. BielskaBrodziak i Z. Tubor (2007: 20) podkreślają, że w naszym kraju wydano ponad 700 orzeczeń, w których słownik był jednym z argumentów na rzez podjętego rozstrzygnięcia;

(v) wykładnia systemowa polega na ustalaniu rzeczywistego znaczenia przepisów ze względu na jego usytuowanie w systematyce wewnętrznej aktu normatywnego lub całej gałęzi prawa (T. Stawecki/ P. Winczorek 2003: 171). Umiejscowienie danego przepisu właśnie $\mathrm{w}$ tym, a nie $\mathrm{w}$ innym miejscu nie jest przypadkowe i stanowi wskazówkę interpretacyjną dla odbiorcy tekstu (tamże);

(vi) wykładnia funkcjonalna nakazuje interpretować przepis zgodnie z prawdopodobnym celem, jaki chciał osiągnąc ustawodawca formułując dany przepis, gałąź prawa lub cały system prawa (T. Stawecki/ P. Winczorek 2003: 172). Czyli przez cel rozumie się zamierzony stan rzeczy, który chce uzyskać prawodawca poprzez stosowanie i przestrzeganie prawa (tamże);

(vii) wykładnia porównawcza polega na ustaleniu znaczenia przepisów przez ich porównanie $\mathrm{z}$ innymi, podobnymi przepisami oraz wyciąganiu z porównania wniosków co do znaczenia interpretowanych przepisów (tamże). Porównuje się przy tym również przepisy prawne pochodzące $\mathrm{z}$ różnych systemów prawnych (tamże $)^{3}$.

Dodać trzeba, iż kwestią sporną jest, czy obowiązuje hierarchia ważności sposobów interpretacji przepisów prawa. Naczelny Sąd Administracyjny w wyroku podkreśla, że nie obowiązuje hierarchia ważności sposobów interpretacji przepisów prawa (Wyrok NSA z z 9.4.1999 r., II S.A. 333/99 niepublikowany cyt. za T. Stawecki/ P. Winczorek 2003: 172). Natomiast T. Stawecki/ P. Winczorek (2003), L. Morawski (2002) i M. Zieliński (2012) są odmiennego zdania, twierdząc, że pod wpływem doktryny pozytywizmu prawniczego przyjęto, iż wykładnia językowa ma pierwszeństwo przed wykładnią systemową, funkcjonalną i zwłaszcza porównawczą.

Pragnę zauważyć, że w świetle ustaleń lingwistyki antropocentrycznej trudno jest mówić o ontycznym oddzieleniu wykładni językowej, funkcjonalnej i systemowej od siebie. Rzeczywista (idio)wiedza specjalistyczna nie jest bowiem czymś w mózgu w stosunku do (idio)wiedzy nie specjalistycznej wyraźnie wyodrębnionym (S. Grucza 2013: 98). Wyodrębnianie (idio)wiedzy prawnej w obrębie pozostałej (idio)wiedzy ma jedynie charakter analityczny (pojęciowy) i przez to arbitralny (S. Grucza 2013: 117).

Przytoczone rodzaje wykładni mogą pomóc tłumaczowi zrekonstruować znaczenie przepisu prawnego. W przypadku wykładni autentycznej tłumacz będzie mógł oprzeć się na definicjach legalnych wyrażonych w danym akcie normatyw-

\footnotetext{
${ }^{3} \mathrm{~W}$ niniejszym tekście wybrane zostały te rodzaje wykładni, które z punktu widzenia autorki niniejszego tekstu, mogą $\mathrm{w}$ największym stopniu przyczynić się do zrozumienia tekstu prawnego przez tłumacza.
} 
nym, czy też na objaśnieniach zamieszczonych w formie załącznika do aktu normatywnego. Wynik wykładni operatywnej i doktrynalnej tłumacz odnajdzie w komentarzach do danego aktu normatywnego, artykułach naukowych oraz podręcznikach prawniczych. Bazując zarówno na definicjach legalnych, komentarzach jak i dorobku doktryny dotyczącego sposobu rozumienia konkretnego przepisu prawnego tłumacz ukierunkuje swój sposób rozumienia znaczenia danego tekstu prawnego.

Zadaniem prawnika jest rekonstrukcja normy prawnej na podstawie różnorodnych przepisów prawnych. Tłumacz natomiast powinien mieć daleko idącą świadomość tego faktu i również uwzględniać w procesie wykładni końcowy cel przepisu, którym jest rekonstrukcja normy prawnej.

Dokonując wykładni tekstów z zakresu prawa należy pamiętać, że prawnicy posługując się metodą dogmatyczną i interpretują przepisy prawne jako elementy składowe norm prawnych, zakładając przy tym brak sprzeczności pomiędzy nimi, co ma umożliwić stworzenie zamkniętego i spójnego systemu prawnego (por. M. Błachut et al. 2008, J. Wróblewski 1990).

Pragnę zauważyć, że pomimo tego, iż celem tłumacza tekstów prawnych jest przetłumaczenie tekstu, nie zaś stosowanie wyrażanych przez ten tekst przepisów prawnych, jak ma to miejsce w przypadku prawników, to jednak pełniejsze rozumienie tekstu tj. przepisu prawnego stanowi bardzo ważny etap w poszukiwaniu odpowiedniego tłumaczenia w języku docelowym. Podkreślić trzeba także, że tłumacz podejmując próbę zrozumienia tekstu prawnego powinien kierować się dyrektywami rozumienia (tj. wykładni), którymi posługuje się autor tekstu wyjściowego, aby możliwie najpełniej zbliżyć się do jego sposobu rozumienia tekstu.

\section{Wykładnia translacyjna przepisów prawa}

Na podstawie poczynionych powyżej stwierdzeń, pragnę zwrócić uwagę na to, że thumacz przechodzi przez poszczególne etapy rozumienia przepisu prawnego rekonstruując jego znaczenie specjalistyczne i buduje w swojej głowie poszczególne elementy normy w celu jego zrozumienia i translacji.

W pierwszej kolejności tłumacz ma do czynienia z graficznie zrealizowaną wypowiedzią językową, która w sobie niczego poza swą graficzną substancją nie zawiera (S. Grucza 2013: 110 i nast.). W żadnym teście, tak też w tekście prawnym, nie zawiera się bowiem żadna treść ani żadne znaczenie, ani żadna wiedza, tym bardziej język (tamże). Należy bowiem wyraźnie odróżnić tekst jako wyrażenie, od tego, co tekst ten w intencji nadawcy wyraża, czyli od rozumienia mu przypisanego (tamże). Ponadto należy odróżnić formy (struktury) tekstu, będące obiektami mentalnymi, czyli elementami wiedzy istniejącymi w mózgu konkretnego mówcysłuchacza od konkretnych realizacji tekstu, czyli eksternalizowanych obiektów istniejących samodzielnie w postaci formy graficznej - szerzej na ten temat wypowiedział się S. Grucza w monografii pt. „Lingwistyka języków specjalistycznych” (2013).

Tłumacz na podstawie tekstu - graficznie lub fonicznie zrealizowanej wypowiedzi językowej - rekonstruuje wiedzę specjalistyczną wyrażoną przez autora. Jeśli zatem autor wyjściowego tekstu prawnego posługuje się określonymi sposobami 
rozumienia i formułowania tekstów prawnych, czyli metodami wykładni, to oznacza to, że tłumacz w celu rekonstrukcji wiedzy specjalistycznej tego autora powinien obrać analogiczną drogę i podjąć próbę dokonania wykładni prawnej w granicach zarysowanych celem, jakim jest przetłumaczenie tekstu.

Stosując wykładnię systemową tłumacz może rekonstruować znaczenie danej instytucji prawnej za pomocą jej umiejscowienia w systematyce rozwiniętej przez daną gałęź prawa. W przypadku wykładni funkcjonalnej tłumacz rekonstruuje hipotetyczny cel ustawodawcy, który pragnie on osiągnąć poprzez wprowadzenie i stosowanie przepisów prawnych. Wykładnia porównawcza tworzy szczególny etap pracy tłumacza, gdyż po dokonaniu rekonstrukcji specjalistycznego znaczenia wyrażenia, czy też instytucji prawnej, następuje poszukiwanie możliwie najbardziej ,,podobnej" konstrukcji myślowej w docelowym systemie prawnym. Zatem poszukiwanie odpowiednika odbywa się niejako ,przez pryzmat” już zrekonstruowanej konstrukcji myślowej.

Ze względu na dogmatyczny charakter prawa konstrukcje prawne w różnych systemach prawnych nie są identyczne. Nawet normy prawne zrekonstruowane przez poszczególnych prawników różnią się między sobą z powodu jednostkowego charakteru ich idiolektu i idiowiedzy. Tłumacz poszukujący podobnej konstrukcji prawnej $\mathrm{w}$ innym systemie prawnym dokonuje poszukiwania poprzez porównanie konstruktów prawnych zrekonstruowanych na podstawie różnych systemów prawnych. Tym samym jego działalność na tym etapie zaczyna przypominać pracę prawników-komparatystów, którzy zaczynają od opisu poszczególnych instytucji, czy też systemów prawnych, w celu ich porównania (szerzej na temat pracy prawnikówkomparatystów wypowiedział się R. Tokarczyk 2008).

Porównując zrekonstruowane znaczenie specjalistyczne fragmentu normy prawnej czy też wyrażenia specjalistycznego w obu systemach prawnych tłumacz podejmuje decyzję interpretacyjną, która dotyczy kompatybilności obu wyrażeń prawnych, czasem fragmentów norm prawnych oraz podejmuje decyzję o ich przetłumaczalności. Podjętą decyzję interpretacyjną tłumacz ocenia z punktu widzenia hipotetycznego odbiorcy tekstu wyjściowego i docelowego, a także rodzaju tekstu oraz celu tłumaczenia. Dodać można, że informacja o podjętych i odrzuconych decyzjach interpretacyjnych tłumacza stanowi cenną wskazówkę dla innych tłumaczy oraz dydaktyki translacji.

Do tej pory wyrażenie ,wykładnia” dotyczyła w doktrynie prawa wyłącznie interpretacji tekstów prawnych. Moim zdaniem warto podjąć próbę powiązania go także z interpretacją tekstów prawniczych, gdyż i ich rozumienie uzależnione jest od porównania przepisów i systemów prawnych. Ponadto tłumacząc terminy prawnicze niewystępujące $\mathrm{w}$ tekstach prawnych, lecz tekstach prawniczych, konieczna jest rekonstrukcja ich znaczenia na podstawie podręczników do nauki danej gałęzi prawa. Szczególna systematyka takich podręczników umożliwia dokonanie wykładni systemowej i funkcjonalnej danego wyrażenia prawniczego. Dodać należy, że sięgnięcie do podręczników prawniczych w celu zrozumienia znaczenia danego wyrażenia prawniczego np. „wadliwość aktów administracyjnych” okazać się może bardzo owocną drogą oraz pomóc dokonać porównania danego wyrażenia prawniczego 
z docelowym systemem prawnym. Podręczniki te dzielą się nie tylko na rozdziały, lecz również na paragrafy, co wprowadza swoistą systematykę. Umiejscowienie danej instytucji prawnej, czy też wyrażenia prawniczego w ramach tej systematyki powinno ułatwić zrozumienia roli i funkcji danego zagadnienia w całej gałęzi prawnej. Autorzy starają się przedstawić w podręczniku obraz systemu prawnego danej gałęzi prawa wraz z ustaleniem hierarchii aktów prawnych dotyczącej tej gałęzi. Wykładnia funkcjonalna natomiast, pomoże odpowiedzieć tłumaczowi na pytanie, jaki stan rzeczy chce ustawodawca osiągnąć, wprowadzając dane rozwiązanie prawne, czyli jakie wartości pragnie w ten sposób chronić. Wykładnię obejmującą wykładnię systemową oraz funkcjonalną danego wyrażenia prawniczego nazywać będę „wykładnią translacyjną tekstów prawniczych".

\section{Dyrektywy wykładni translacyjnej przepisów prawnych}

Część niniejsza poświęcona będzie przedstawieniu dyrektyw wykładni translacyjnej, których zrealizowanie powinno pomóc thumaczowi ukierunkować rekonstrukcję znaczenia przepisu prawnego. Dyrektywy wykładni translacyjnej przedstawione w niniejszej części zaczerpnięte zostały przede wszystkim od M. Zielińskiego (2012) oraz w mniejszym stopniu od L. Morawskiego (2012), którzy przedstawiają poszczególne kroki wykładni tekstów prawnych, w celu rekonstrukcji znaczenia poszczególnych przepisów prawnych. Na każdym etapie wykładni musi zapaść dostatecznie uzasadniona cząstkowa decyzja interpretacyjna.

Zważywszy na to, że zadaniem tłumacza nie jest stosowanie przepisu prawnego do konkretnego stanu faktycznego lecz rekonstrukcja znaczenia przepisu prawnego pod kątem częściowego odtworzenia normy prawnej, aby móc przybliżyć się do sposobu rozumienia autora tekstu wyjściowego, dyrektywy te będą w znaczącym stopniu zakrojone na potrzeby pracy tłumacza. Za M. Zielińskim przyjęte dyrektywy wykładni zostaną podzielone na zasady wykładni, te natomiast na reguły wykładni. Ponadto również wychodzę z założenia, że procesowi wykładni musi być poddane każde wyrażenie, aby osiągnąć jego zrozumienie (podobnie M. Zieliński 2012: 315). Stąd nasuwa się wniosek, że każdemu wyrażeniu zaczerpniętemu z przepisu prawnego można przypisać znaczenie specjalistyczne, rekonstruowane za pomocą poniższych reguł.

\section{Dyrektywy ogólne:}

(i) procesowi wykładni należy poddać każdy przepis prawny (tekst prawny) $\mathrm{w}$ celu jego zrozumienia;

(ii) każdą decyzję kończącą całą wykładnię, a także decyzje kończące poszczególne fragmenty wykładni należy uzasadnić;

(iii) w toku wykładni należy pomocniczo uwzględniać zasady legislacji, a wśród nich zwłaszcza zasady techniki prawodawczej;

(iv) w toku wykładni należy pomocniczo uwzględniać dokonania doktryny. 


\section{Dyrektywy rekonstrukcyjne}

Zasada 1. Proces rekonstrukcji należy rozpocząć od analizy składni przepisu prawnego.

Reguła 1. Proces wykładni danego przepisu należy rozpocząć od ustalenia, czy dany przepis jest jednozdaniowy, czy wielozdaniowy. Należy uwzględnić przy tym zakończenie zdań zarówno przy użyciu kropki, jak i średnika oraz sposób formułowania podpunktów: punkty, litery, tiret i spójników alternatywnych.

Reguła 2. Biorąc pod uwagę przepis jako pojedyncze zdanie należy ustalić, czy jest on przepisem zrębowym ${ }^{4}$, czy niezrębowym. Przepis jest zrębowy, gdy wymienia $\mathrm{A}, \mathrm{O}, \mathrm{n} / \mathrm{z}$ i $\mathrm{Z}^{5}$ albo $\mathrm{A}, \mathrm{n} / \mathrm{z}$ i $\mathrm{Z}$ albo $\mathrm{O}, \mathrm{n} / \mathrm{z}$ i $\mathrm{Z}$ albo co najmniej $\mathrm{n} / \mathrm{z}$ i Z; inny przepis jest niezrębowy.

Reguła 3. W przypadku, gdy przepis ma konstrukcję nienormatywną (opisową), zrekonstruowanie przepisu polega na odtworzeniu zeń w pierwszym etapie wyrażenia normokształtnego.

Reguła 4. Jeśli przepis zawiera zwrot typu „uczyni” („,czyni”) w odniesieniu do czynności konwencjonalnej, należy go rozumieć w ten sposób, iż ustanawia on dwie normy: normę kompetencyjną i nakazującą z kompetencji skorzystać.

Reguła 5. Jeśli przepis odnosi się do czynności konwencjonalnej i występuje w nim zwrot „może”, należy założyć, że wysławia on tylko normę kompetencyjną.

Reguła 6. Wskazując podmioty kompetentne przepis „wysławia” tyle norm, ile jest tych podmiotów.

Reguła 7. Przepis zrębowy należy rozumieć jako przepis samodzielny, natomiast przepis niezrębowy należy interpretować w kontekście przepisu zrębowego.

Reguła 8. Przepis zrębowy jest zupełny, jeśli dadzą się z niego odtworzyć wszystkie elementy normy (A, O, n/z i Z). Jeśli da się z niego odtworzyć tylko n/z i Z (i ewentualnie $\mathrm{A}$ albo $\mathrm{O}$ ) jest to przepis zrębowy niezupełny.

Reguła 9. W przypadku niezupełności normatywnej przepisu należy odszukać elementy uzupełniające (tj. określenie adresata lub okoliczności). Poszukiwać należy w obok przepisu zrębowego, zatem wśród przepisów szczegółowych, w przepisach ogólnych do przedmiotowego aktu, w przepisach aktu proceduralnego $\mathrm{w}$ stosunku do przedmiotowego aktu, w przepisach aktów organizacyjnych.

Reguła 10. Obok uzupełnień normatywnych należy dokonać uzupełnień logicznych ( $\mathrm{tj}$. dodać niezbędne relatywizacje). Uzupełnienia logiczne odnaleźć, czytając przepisy obok (przed lub po) przepisu zrębowego bądź przepisach, do których sam przepis zrębowy odsyła.

\footnotetext{
${ }^{4}$ Przepis jest zrębowy, jeśli sformułowany jest przy użyciu następujących wyrażeń: normatywnych (np. „nakazuje się”, „niech”), hybrydowo-normatywnych (np. „zabrania się”), powinnościowych (z użyciem słowa ,powinien”), modalnych (np. „musi być”), opisowych z użyciem zwrotu (np. ,jest (z)obowiązany”). Przepisem zrębowym nazwać można również przepis, w którym użyto czasownika w czasie teraźniejszym np. „wydaje” lub w czasie przyszłym np. „wyda”. (M. Zieliński 2012: 326).

${ }^{5}$ Podane oznaczenia należy rozumieć w sposób następujący „A” - adresat, „O” - okoliczności, ,n/z” - nakaz/zakaz i „Z” - zachowanie się (M. Zieliński 2012: 109).
} 
Reguła 11. Następnie należy ustalić, czy przepis (uzupełniony) zrębowy, jest przepisem ,treściowo pełnym”, czyli w tekście prawnym nie ma przepisów go modyfikujących. Aby sprawdzić, czy w stosunku do przepisu występują w tekście modyfikatory, należy prześledzić: sąsiednie przepisy szczegółowe, które umiejscowione są przed oraz po analizowanym przepisie, przepisy proceduralne, organizacyjne, przepisy ustaw tematycznie zbliżonych do tematyki przedmiotowego aktu.

Reguła 12. Po odnalezieniu modyfikatorów należy przeformułować wyrażenie normokształtne w sposób uwzględniający modyfikatory.

Zasada 2. ${ }^{6}$ Proces postępowania na tym etapie należy rozpocząć od analizy poszczególnych wyrażeń. Należy ustalić znaczenie przepisu przez ostateczne ustalenie znaczeń wszystkich wyrażeń (tj. poszczególnych słów lub zbitek słownych), bez pominięcia któregokolwiek z nich.

Reguła 13. Należy najpierw zdecydować, czy zwrot składowy, którego sens się ustala, jest wyrazem (np. ,pokrzywdzony”, ,sąd”), czy zbitką słów (np. „oskarżyciel posiłkowy”, czy „stan wyższej konieczności”, ,sąd wojewódzki”).

Reguła 14. Należy poszukiwać znaczenia odpowiednio wyrazu lub całej zbitki słów. Jeśli brak jest takiej możliwości, należy ustalać znaczenie zbitki słów na podstawie ustalenia znaczenia pojedynczych słów (np. przez ustalenie, co znaczy słowo ,transport” i słowo ,kolejowy” dla ustalenia wyrażenia ,transport kolejowy".

Reguła 15. Należy w związku z tym najpierw sprawdzić, czy w tekście prawnym występuje definicja legalna danego słowa lub zbitki słownej. Definicji legalnej należy szukać w pierwszej kolejności w przedmiotowym akcie prawnym.

Reguła 16. Jeśli nie ma definicji w danym akcie prawnym, a akt ten jest ustawą, należy sprawdzić, czy definicja taka występuje w kodeksie regulującym dziedzinę regulowaną przez daną ustawę, w innej ustawie uznanej za podstawową dla danej dziedziny; jeśli definicja jest, należy ją uwzględnić.

Reguła 17. Jeśli nie ma definicji legalnej, należy sprawdzić, czy w ustawie sformułowane jest oddzielne upoważnienie dla aktu wykonawczego do wprowadzenia w nim definicji terminów ustawowych; jeśli takie upoważnienie jest, należy sprawdzić w stosownym akcie wykonawczym, czy jest w nim definicja interpretowanego zwrotu.

Reguła 18. Szukając definicji legalnej w danym akcie, należy w pierwszej kolejności sprawdzić, czy w tekście tego aktu znajduje się tzw. słowniczek określeń ustawowych w oddzielnym rozdziale, zwykle zamieszczonym na końcu przepisów ogólnych, a w przypadku, gdy nie wydzielono słowniczka w odrębny rozdział, może on być zamieszczony w którymś z początkowych przepisów ogólnych. Jeśli w takim słowniczku sformułowana jest definicja interpretowanego terminu, należy ją uwzględnić.

\footnotetext{
${ }^{6} \mathrm{Na}$ tym etapie powinniśmy już być w stanie odtworzyć znaczenie wyrażenia normokształtnego.
} 
Reguła 19. Jeśli w słowniczku nie ma stosownej definicji, należy sprawdzić, czy definicja taka znajduje się w pobliżu przepisu z interpretowanym zwrotem, czy też definicja taka sformułowana jest samodzielnie (tzn. poza słowniczkiem) w przepisach ogólnych danego aktu (tak jest np. w przypadku definicji takich terminów, jak ,zbrodnia” i ,występek” w Kodeksie karnym).

Reguła 20. Jeśli nie ma definicji w przepisach ogólnych danego aktu, należy sprawdzić, czy jest taka definicja w przepisach ogólnych tej jednostki systematyzacyjnej (np. części czy księgi), w której znajduje się interpretowany zwrot.

Reguła 21. Jeśli nie ma definicji samodzielnej, należy sprawdzić, czy w tekście któryś z przepisów tego tekstu nie formułuje definicję nawiasową interpretowanego zwrotu; jeśli jest, należy ją uwzględnić.

Reguła 22. W przypadku definicji legalnej należy ją poddać procedurom wykładni wedle procedur odnoszących się do innych przepisów.

Reguła 23. W przypadku odnalezienia definicji legalnej należy ustalić, czy jest to definicja treściowa, czy zakresowa ${ }^{7}$.

Reguła 24. W przypadku definicji zakresowej, następnie należy ustalić, czy jest ona definicją niepełną (otwartą) (zawiera charakterystyczny zwrot „w szczególności”).

Reguła 25. W przypadku zdiagnozowania definicji zakresowej niepełnej, należy mieć na uwadze, że w orzecznictwie lub nauce dokonano stosownych uzupełnień.

Reguła 27. Jeśli w stosownym tekście prawnym brak jest definicji legalnej interpretowanego zwrotu, należy przede wszystkim sprawdzić, czy zwrot ten ma swoje ustalone znaczenie prawnicze (np. „,własność”, „zabić”, których precyzowaniem nauka i orzecznictwo zajmują się od lat).

Reguła 28. Stosowna definicja takiego zwrotu powinna być wyrażona w podręcznikach (z określonej dziedziny), komentarzach lub adekwatnych tematycznie monografiach (uwzględniających zawsze również stanowisko orzecznictwa).

Reguła 29. Jako ustalone znaczenie prawnicze należy przyjąć tylko to, co do którego większość przedstawicieli doktryny się zgadza.

Reguła 30. W przypadku, gdy w stosunku do interpretowanego zwrotu w literaturze prawniczej nie zajęto jednolitego stanowiska, interpretowany zwrot jest typowym zwrotem faktycznym (np. „drzewo”) albo jest przyimkiem, to jego znaczenie należy ustalać na podstawie słowników ogólnych języka polskiego posiłkując się również słownikami frazeologicznymi w celu zapoznania się z typowymi złożeniami, w których występuje interpretowany zwrot, z tym, że w przypadku spójników i niektórych zaimków odwołać się należy również do logiki. Należy odszukać definicję słownikową najlepiej w kilku słownikach ogólnych języka polskiego, posiłkując się ewentualnie słownikami wyrazów obcych (zwłaszcza, jeśli interpretowany zwrot nadal brzmi obco) i eufemizmów. Warto również skorzystać ze słownika synonimów i słowników dystynktywnych.

${ }^{7}$ Definicja treściowa ma na ogół strukturę: $A=B$ o cechach C. Definicja zakresowa ma strukturę: A = B lub C lub D lub E (M. Zieliński 2012: 333). 
Reguła 31. W odniesieniu do spójników ,i”, ,albo”, „lub”, „oraz”, ,jeżeli to”, należy również skorzystać z podręczników logiki dla prawników.

Reguła 32. Następnie należy skonfrontować uzyskane rezultaty na podstawie różnych słowników. W przypadku wieloznaczności danego zwrotu należy zapoznać się z jego antonimami.

Reguła 33. Następnie należy sprawdzić, jakie znaczenie ma zwrot na gruncie szerszego kontekstu. Należy uwzględnić najbliżej sąsiadujące wyrazy, całe zdania, sąsiednie zdania. Ponadto należy uwzględnić osadzenie danego przepisu w danej jednostce systematyzacyjnej (np. część, księga wraz z jej tytułem) oraz kontekst najszerszy obejmujący cały akt (wraz z jego tytułem).

Zasada 3. Należy dokonać wykładni systemowej ${ }^{8}$ otrzymanego wyrażenia normokształtnego, gdyż ,żadnego przepisu ustawy [...] nie można interpretować w oderwaniu od jej pozostałych przepisów" (NSA w uchwale z 29.05.2000 r., FPS 2/00, ONS 2001/1/2).

Reguła 34. Przepisy prawne należy interpretować biorąc pod uwagę ich miejsce w systematyce zewnętrznej i wewnętrznej aktu normatywnego. Mówiąc o systematyce zewnętrznej mam na myśli gałąź prawa, do której należy dany przepis, jak i wewnętrznej aktu prawnego (w jakim dziale, rozdziale etc. aktu normatywnego został on umieszczony, czy należy do przepisów ogólnych, czy szczegółowych itd.)

Reguła 35. Z systematyką zewnętrzną zapoznać się można studiując podręcznik do danej gałęzi prawa. Spisy treści takich podręczników podzielone są na paragrafy, co ułatwia zapoznanie się z systematyką gałęzi prawa. Natomiast systematykę wewnętrzną poznajemy zapoznając się z danym aktem prawnym. Przy tym należy zwrócić uwagę na to, że akty normatywne publikowane w Dzienniku Ustaw nie posiadają spisu treści. Spis treści konkretnej ustawy wraz z indeksem rzeczowym znajduje się w wydaniach aktów prawnych takich wydawnictw jak np. C.H. Beck, czy Lexis Nexis.

Reguła 36. Przepisy prawne powinny być interpretowane w sposób zgodny z zasadami prawa. Jeśli brak jest wskazówek w akcie normatywnym, to o uznaniu przepisu za zasadę prawa decyduje ostatecznie orzecznictwo i doktryna. Zasady prawa odnoszące się do danej gałęzi prawa wyrażone są w podręcznikach do nauki danej gałęzi prawa oraz odpowiednich monografiach. Na to, że zasady mogą być ujmowane jako dyrektywy interpretacyjne wskazuje Trybunał Konstytucyjny w wyroku z 10.07.2000 (SK 12/99, OTK 2000/5/143).

Reguła 37. Interpretując przepisy prawne należy mieć na względzie przede wszystkim zasady konstytucyjne. Nakaz interpretacji wszystkich przepisów w sposób zgodny z konstytucją jest nie tylko obowiązkiem Trybunału Konstytucyjnego, ale wszystkich organów i podmiotów interpretujących prawo.

Reguła 38. Interpretując przepisy prawne należy mieć na uwadze hierarchię aktów normatywnych, gdyż przepisy niższego rzędu muszą być interpretowane przez

8 Wykładnia systemowa będzie rozumiana zgodnie $\mathrm{z}$ przedstawionymi poniżej regułami zaczerpniętymi z L. Morawskiego (2002: 261-198) i odpowiednio zmodyfikowanymi na potrzeby pracy thumacza. 
prawników zgodnie z treścią przepisów hierarchicznie wyższych. Należy zrekonstruować hierarchię aktów normatywnych na podstawie art. 87 Konstytucji (,Źródłami powszechnie obowiązującego prawa Rzeczypospolitej Polskiej są: Konstytucja, ustawy, ratyfikowane umowy międzynarodowe oraz rozporządzenia"). Ponadto podręczniki do nauki danej gałęzi prawa doprecyzowują znaczenie przypisywane kodeksom oraz aktom wykonawczym na gruncie danej gałęzi prawa.

Zasada 4. W następnej kolejności należy dokonać wykładni funkcjonalnej ${ }^{9}$ danego przepisu prawnego. Takiej wykładni wymagają szczególnie wyrażenia niedookreślone, terminy wartościujące i klauzule generalne.

Reguła 39. Interpretując przepisy prawne należy brać pod uwagę cel regulacji prawnej (ratio legis). Należy ustalić go uwzględniając cele prawa w ogóle oraz gałęzi prawa, a także danego aktu normatywnego. Cel przepisu należy ustalić w ten sposób, aby był zgodny co najmniej z celami instytucji, do jakiej interpretowany przepis należy (por. J. Wróblewski 1988).

Reguła 40. Przepisy prawne należy interpretować zgodnie z wolą prawodawcy. Prawo powinno być pojmowane jako wyraz woli demokratycznie wybranych przedstawicieli narodu. W ustalaniu ,woli” prawodawcy szczególnie pomocne mogą się okazać sprawozdania różnego rodzaju komisji legislacyjnych, sprawozdania z obrad parlamentu, czy rządu (tzw. materiały przygotowawcze). Podręczniki prawnicze do nauki danej gałęzi prawa w sposób kompaktowy zarysowują cele konkretnych przepisów prawnych.

Reguła 41. W ustaleniu celu regulacji prawnej oraz woli prawodawcy preambuła (wstęp) do danego aktu normatywnego odgrywa bardzo ważną rolę.

Reguła 42. Przy wykładni przepisów prawnych należy brać pod uwagę powszechnie akceptowane normy moralne, zasady sprawiedliwości i słuszności. Sposób ich rozumienia $\mathrm{w}$ sposób szczegółowy przedstawiają w szczególności podręczniki do nauki doktryn polityczno-prawnych (np. H. Izdebskiego) oraz artykuły uznanych prawników dotyczące zagadnień filozofii prawa (np. H.L.A. Harta).

Na koniec trzeba podkreślić, że przedstawione dyrektywy nie stanowią zamkniętego i zupełnego katalogu. Są to uporządkowane pod kątem potrzeb tłumacza ogólne dyrektywy wykładni zaczerpnięte $\mathrm{z}$ literatury prawniczej skierowane zarówno do prawników, jak i osób chcących dokonać wykładni prawa oraz zakrojone na potrzeby pracy tłumacza. Celem wykładni dokonywanej przez tłumacza nie jest zatem stosowanie wyinterpretowanej normy prawnej do konkretnej sytuacji faktycznej, lecz zrozumienie przepisu prawnego w sposób możliwie zbliżony do autora tekstu.

Warto wskazać, że powyższe dyrektywy dotyczą jedynie wykładni translacyjnej przepisu prawnego. Natomiast dla odnalezienia tłumaczenia nazwy instytucji prawnej, czy wyrażenia prawnego konieczna jest nie tylko wykładnia translacyjna przepisu wyjściowego, lecz również wykładnię przepisów prawnych z docelowego systemu prawnego oraz wykładnię porównawczą zrekonstruowanego przepisu wyjścio-

${ }^{9}$ Wykładnia funkcjonalna rozumiana będzie zgodnie $\mathrm{z}$ regułami przedstawionymi poniżej, zaczerpniętymi z (Z. Zieliński 2012: 341-344 i L. Morawski 2002: 201-226). 
wego, jak i docelowego. W następnej kolejności otrzymany rezultat powinien zostać przeanalizowany pod kątem dyrektyw translacyjnych, tj. odbiorcy tekstu wyjściowego, docelowego, rodzaju tekstu oraz celu thumaczenia. Otrzymany wynik powinien być ponadto poddany ocenie z punktu widzenia skutków prawnych, które wywołać może wybrany przez tłumacza odpowiednik docelowy.

\section{Podsumowanie}

Moim zdaniem warto podjąć próbę powiązania wyrażenia „wykładnia” z interpretacją translacyjną tekstów prawnych i prawniczych. Zarówno M. Zieliński (2012: 12), jak i T. Stawecki/ P. Winczorek (2003: 170) podkreślają powszechność wykonywania prywatnej wykładni tekstów prawnych przez osoby nie będące prawnikami, którzy są świadomi konsekwencji zasady ignorantia iuris nocet (nieznajomość prawa szkodzi). Zatem thumacze zajmujący się zawodowo przekładem tekstów prawnych i prawniczych zmuszeni są dokonywać wykładni tekstów prawnych nie tylko z tytułu świadomości konsekwencji prawnych nieznajomości prawa, lecz również z tytułu obowiązków zawodowych.

Wykładnią translacyjną można określić zatem czynności mentalne nakierowane na rekonstrukcję wiedzy prawnej i/lub prawniczej autora tekstu na podstawie nie tylko określenia rodzaju tekstu, hipotetycznego odbiorcy oryginału i thumaczenia oraz celu thumaczenia, lecz także na podstawie metod rozumowania, którymi posługują się prawnicy - autorzy tych tekstów. Przy tym wykładnia nazwy instytucji prawnej pochodzącej z docelowego systemu prawnego odbywa się przez pryzmat jej kompatybilności z instytucją prawną z tekstu wyjściowego. Oznacza to, że miarą wykładni instytucji prawnej pochodzącej z docelowego systemu prawnego jest instytucja prawna $\mathrm{z}$ tekstu wyjściowego, natomiast wynikiem wykładni translacyjnej jest ostateczna decyzja interpretacyjna thumacza dotycząca kompatybilności i wyboru określenia dla danej instytucji prawnej, czy tez wyrażenia prawnego.

\section{Bibliografia}

Bielska-Brodziak A./ Z. Tubor, (2007), Stowniki a interpretacja tekstów prawnych, (w:) „Państwo i prawo” 5(735), 20-33.

Błachut M./ J. Kaczor/ P. Kaczmarek et al. (2008), Systemowość w myśleniu prawniczym, (w:) O. Bogucki/ S. Czepita (red.), System prawny a porządek prawny. Szczecin, 89-109.

Gizbert-Studnicki T. (1986), Język prawny z perspektywy socjolingwistycznej. Warszawa.

Grucza S. (2013), Lingwistyka języków specjalistycznych. Warszawa.

Konstytucja Rzeczypospolitej Polskiej z dnia 2 kwietnia 1997 r. Dz.U. 1997 nr 78 poz. 483 z późn. zm.

Stawecki T./ P. Winczorek (2003), Wstęp do prawoznawstwa. Wyd. 4. Warszawa.

Tokarczyk R. (2008), Komparatystyka prawnicza. Wyd. 9. Warszawa.

Wróblewski, J. (1988), Sadowe stosowanie prawa. Warszawa. 
Wróblewski J. (1990), Paradygmat dogmatyki prawa a prawoznawstwo, (w:) S. Wronkowska/ M. Zieliński (red.), Szkice z teorii prawa i szczegółowych nauk prawnych. Poznań, 43-58.

Zieliński M. (2012), Wykładnia prawa. Zasady, reguły, wskazówki. Wyd. 6. Warszawa.

Uchwała Sądu Najwyższego z dnia 18.9.1989 r., VI KZP 10/82.

Uchwała Naczelnego Sądu Administracyjnego z dnia 29.05.2000 r., FPS 2/00, ONS 2001/1/2.

Wróblewski, J. (1990), Rozumienie prawa i jego wykładnia. Kraków/ Warszawa etc.

Wyrok Naczelnego Sądu Administracyjnego z dnia 9.4.1999 r., II S.A. 333/99 (niepublikowany).

Wyrok Trybunał Konstytucyjny z dnia 10.07.2000 r., SK 12/99, OTK 2000/5/143. 